\title{
STUDI PERBANDINGAN PENERAPAN MODEL PEMBELAJARAN TWO STAY TWO STRAY DAN JIGSA W DITINJAU DARI HASIL BELAJAR MATEMATIKA
}

\section{THE COMPARASION OF COOPERATIF MODEL TWO STAY TWO STRAY AND JIGSAW TYPES TOWARD LEARNING OUTCOMES OF MATEMATIC}

\author{
Sibtil Hasaniah*, Laila Hayati dan Nani Kurniati \\ Program Studi Pendidikan Matematika FKIP Universitas Mataram, Indonesia \\ Email: sibti197@gmail.com
}

Diterima: 10 Mei 2020. Disetujui: 14 Februari 2021. Dipublikasikan: 3 Maret 2021

\begin{abstract}
Abstrak: Penelitian ini bertujuan untuk mengetahui perbandingan model pembelajaran kooperatif tipe two stay two stray dan model pembelajaran kooperatif tipe jigsaw ditinjau dari hasil belajar siswa pada materi pola dan barisan bilangan siswa kelas VIII di SMPN 1 Gunungsari tahun pelajaran 2019/2020. Penelitian eksperimen ini merupakan jenis quasi eksperimental design dengan desain post test only. Teknik pengambilan sampel dalam penelitian iniyaitu teknik cluster random sampling yaitu kelas VIII-A dan VIII-C.Instrumen yangdigunakan adalah tes berupa soal-soal uraian dan lembarobservasi yaituketerlaksanaan pembelajaran, aktivitas guru dan aktivitas siswa. Hasil belajar siswa pada kelas two stay two stray memperoleh rata-rata 63,67 dengan ketuntasan klasikal 26,66\%. Sedangkan kelas jigsaw memperoleh rata-rata hasil belajar 65,33 dengan ketuntasan klasikal $30 \%$. Meskipun hasil belajar yang diperoleh kedua kelas masih rendah, namun aktivitas belajar siswa mengalamipeningkatan setiap pertemuannya. Pelaksanaan pembelajaran pada kedua kelas sudah terlaksana sangat baik dengan tingkat keterlaksanaan 97\%. Selain itu, aktivitas guru juga sudah sesuai dengan rencana pelaksanaan pembelajaran. Berdasakan hasil uji t diperoleh bahwa nilai $t$ tabel 0,48 dan $t$ hitung 2,00 yang berarti hasil belajar kelas VIII-A sama dengan kelas VIII-C. Hasil penelitian diperoleh bahwa tidak terdapat perbedaan yang signifikan antara model pembelajaran kooperatif tipe two stay two stray dan model pembelajaran kooperatif tipe jigsaw ditinjau dari hasil belajar siswa pada materi pola dan barisan bilangan siswa kelas VIII di SMPN 1 Gunungsari tahun pelajaran 2019/2020.
\end{abstract}

Kata kunci: Model Pembelajaran Kooperatif, Two Stay Two Stray, Jigsaw, Hasilbelajar Matematik

\begin{abstract}
This study was aimed to discover the comparison of the cooperative learning model between two stay two stray type and jigsaw typeon thesubject of patterns and row of numbers in SMPN 1 Gunungsari academic year 2019/2020. This researchis considered as quasi experiment group design in whish post test was used. The sample was taken using cluster random sampling, students of VIII-A and VIII-C were used as the sampel. The instruments used in this research were written test and observation sheets consisting of learning process, teacher and student's activities. The students' score in using the two sttay two stray class shows an average score 63.67 with $26.66 \%$ classical completeness. While in the jigsaw class,the average of students' score was 65.33 with $30.00 \%$ classical completeness. Although the result of both classes are low, but both classes have increased learning activities each meeting. The implementation of the learning model has been carried out $97 \%$. Furthermore, teacher activities were coresponded with the study plans. Based on the t-results found that the value of $\mathrm{t}$ tabel 0,48 and $\mathrm{t}$ count 2,00 which means VIII-A and VIII-C is same. The result of this study shows that there is no significant differences between two stay two stray typeand jigsaw type in cooperative learning modelon thesubject of patterns and row of numbers in VIII grade SMPN 1 Gunungsari academic year 2019/2020.
\end{abstract}

\begin{tabular}{l} 
Keywords: $\begin{array}{l}\text { Cooperative Learning Model, Two Stay Two Stray, Jigsaw, Learning, Outcome, } \\
\text { Mathematic }\end{array}$ \\
\hline
\end{tabular}

\section{PENDAHULUAN}

Kurikulum 2013 menghendaki kualitas pembelajaran yang menjadikan sikap siswa kreatif, mandiri, kerjasama, solidaritas, kepemimpinan, toleransi dan kecakapan hidup siswa guna membentuk watak serta meningkatkan peradaban martabat bangsa [5]. SMP Negeri 1 Gunungsari adalah salah satu sekolah negeri di Lombok Barat yang sudah menerapkan kurikulum 2013. Berdasarkan observasi di kelas nampak bahwa pihak sekolah telah menyiapkan bahan ajar berupa buku paket matematika revisi 2017.

Berdasarkan hasil observasi juga didapatkan bahwa aktivitas siswa di kelas masih sangat kurang. Terlihat beberapa siswa hanya memperhatikan namun tidak memberikan respon bahkan ada yang tidur di dalam kelas ketika pembelajaran. Siswa tidak merespon ketika guru menanyakan mengenai pemahaman siswa sehingga guru juga kesulitan dalam mengatasi hal tersebut. 
Akibatnya, hasil belajar siswa yang menjadi semakin rendah. Hasil belajar adalah Hasil belajar merupakan kemampuan-kemampuan yang dimiliki siswa setelah menerima pengalaman belajarnya [8,10,11]. Rendahnya hasil belajar siswa tidak hanya disebabkan oleh kemampuan intelektual siswa itu sendiri, melainkan juga proses belajar yang belum sesuai tuntutan kurikulum yang berlaku. Akibatnya proses pembelajaran kurang memberikan kesempatan kepadasiswa untuk mengembangkan potensi yang dimiliki.

Dari hasil obseravsi terlihat bahwa siswa lebih senang berdiskusi dengan teman-teman sebayanya dibandingkan dengan bertanya kepada guru. Bahkan dari hasil wawancara dengan dua orang siswa diperoleh informasi bahwa mereka merasa segan untuk bertanya kepada guru. Diskusi bersama teman sebaya memungkinkan berlangsungnya proses diskusi yang lebih aktif. Untuk mengatasi permasalahan tersebut maka diperlukan solusi yang tepat dengan mengutamakan aspek potensi siswa, salah satu caranya yaitu dengan menerapkan model pembelajaran yang dapat memfasilitasi potensi dalam kelas. Model pembelajaran yang dapat diterapkan salah satunya adalah model pembelajaran kooperatif.

Model pembelajaran kooperatif tipetwo stay two straydan jigsawadalah dua dari banyaknya tipe pembelajaran model kooperatif. Kedua tipe ini memiliki karakteristik yang hampir sama. Dalam penerapannya, kedua tipe ini menuntut kerjasama kelompok yang bagus dan interaksi dengan kelompok lain yang baik. Berhasil tidaknya proses pembelajaran ditentukan oleh siswa itu sendiri bersama anggota kelompoknya. Penerapan model pembelajaran ini diharapkan dapat meningkatkan hasil belajar siswa. Meski memiliki persamaan karakteristik model pembelaajaran kooperaatif tipe two stay two stray dan jigsaw memiliki perbedaan pada sistem diskusi. perbedaan ini dapat menimbulkan adanya perbedaan pada hasil belajar.

Tabel 1. Sintak Model Pembelajaran Kooperatif Tipe Two Stay Two Stray

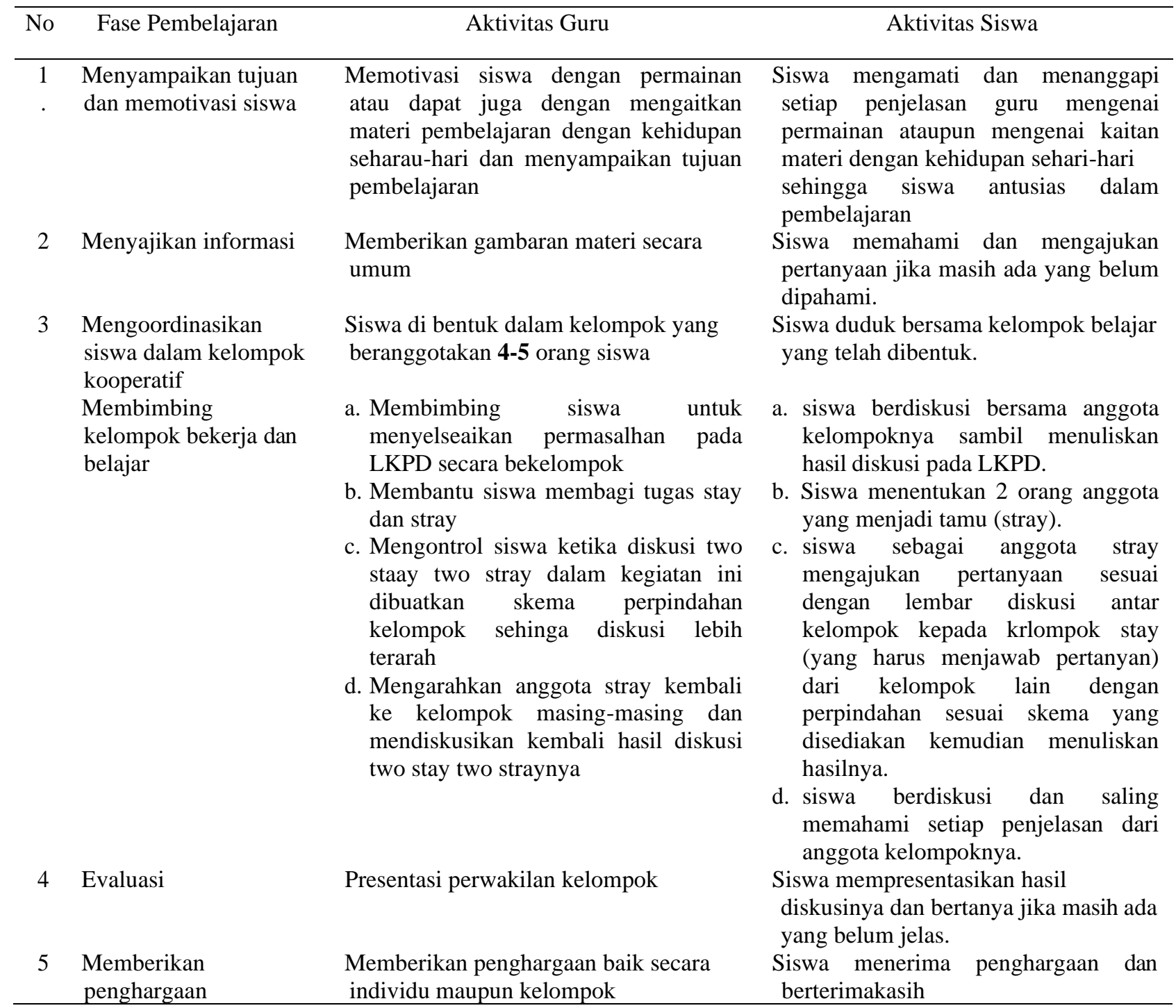


Tujuan dari penelitian ini adalah Untuk mendeskripsikan hasil belajar dengan model pembelajaran kooperatif tipe two stay two stray dan jigsaw setelah diterapkan pada siswa kelas VIII SMPN 1 Gunungsari tahun pelajaran 2019/2020. Selain itu juga untuk mengetahui perbedaanhasil belajar matematika siswa pada materi pola dan barisan bilangan kelas VIII SMPN 1 Gunungsari menggunakan model pembelajaran kooperatif tipe two stay two stray dan jigsaw tahun pelajaran 2019/2020.

Secara umum langkah-langkah model pembelajaran kooperatif tipetwo stay two stray yang telah dikembangkan oleh peneliti dengan mengacu pada [9] dapat dilihat pada tabel 1.

Sedangkan langkah-langkah model pembelajaran kooperatif tipe jigsaw yang telah dikembangkan oleh peneliti dengan mengacu pada $[9,12]$ dapat dilihat pada tabel 2 .

Tabel 2. Sintak Model Pembelajaran Kooperatif Tipe Jigsaw

\begin{tabular}{cll}
\hline No & Fase Pembelajaran & \multicolumn{1}{c}{ Aktivitas Guru } \\
\hline 1. & $\begin{array}{l}\text { Menyampaikan } \\
\text { tujuan } \\
\text { memotivasi siswa }\end{array}$ & $\begin{array}{l}\text { Memotivasi siswa dengan permainan } \\
\text { atau dapat juga dengan mengaitkan } \\
\end{array}$ \\
& $\begin{array}{l}\text { materi pembelajaran dengan kehidupan } \\
\text { seharau-hari dan menyampaikan tujuan } \\
\text { pembelajaran }\end{array}$
\end{tabular}

2. Menyajikan informasi

\section{Memberikan gambaran materi secara umum}

3. Mengoordinasikan siswa dalam kelompok kooperatif

4. Membimbing kelompok bekerja dan belajar

\section{Evaluasi}

6. Memberikan penghargaan
Siswa di bentuk dalam kelompok yang beranggotakan 6 enam) orang siswa (kelompok asal)

a. Membimbing peembagiaan sub topik pada setiap anggota kelompok yang dibantu dengan lembar materi sehngga memudahkan pembagian.

b. Guru mengarahkan siswa untuk membentuk kelompok baru (kelompok ahli) berdasarkan pembagian tugas kelompok asal kemudian membimbing siswa berdiskusi untuk menyelesaikan tugas yang diperoleh dari kelompok asal.

c. Mengarahkan siswa untuk kembali ke kelompok sebelumnya (kelompok asal) dengan membawa LKPD.

d. Membimbing Setiap anggota menjelaskan hasil diskusi mereka dalam kelompok ahli kepada kelompok asal

Presentasi perwakilan kelompok

Memberikan penghargaan baik secara individu maupun kelompok
Aktivitas Siswa

Siswa mengamati dan menanggapi setiap penjelasan guru mengenai permainan ataupun mengenai kaitan materi dengan kehidupan sehari-hari sehingga siswa antusias dalam Pembelajaran

Siswa memahami dan mengajukan pertanyaan jika masih ada yang belum dipahami.

Siswa duduk bersama kelompok belajar yang telah dibentuk.

a. siswa berdiskusi bersama anggota kelompoknya (asal) untuk membagi tugas setiap anggota kelompok.

b. Siswa dengan sub topik yang sama berkkumpul mendiskusikan materi mereka (kelompok ahli) yang telah disajikan dalam LKPD ahli kemudian menuliskan kembali hasil diskusinya pada LKPD

c. siswa kembali ke kelompok asal

d. siswa berdiskusi dengan saling menjelaskan dan bertanya jika masih ada yang belum dimengerti dan mencatat hasilnya pada lembar diskusi

Siswa mempresentasikan hasil diskusinya dan bertanya jika masih ada yang belum jelas.

Siswa menerima penghargaan dan berterimakasih

\section{METODE PENELITIAN}

Jenis penelitian yang digunakan oleh peneliti adalah penelitian eksperimen quasi eksperimental design dengan desain post test only dan nilai ujian tengah smester sebagai data awal siswa. Variabel dalam penelitian ini berupa variabel terikat dan variable bebas. Variabel bebas dalam penelitian ini adalah model pembelajaran kooperatif tipe two stay two stray dan jigsaw, sedangkan variabel terikatnya adalah hasil belajar matematika pada siswa kelas VIII SMPN 1 Gunungsari tahun pelajaran 2019/2020. Populasi dalam penelitian ini adalah siswa kelas VIII SMPN 1 Gunungsariyang terdiri dari 236 
siswa dan dibagi menjadi 8 kelas. teknik sampling yang digunakan adalah cluster random sampling karena data siswa kelas VIII SMPN 1 Gunungsari homogen. Dengan cara diundi terambilah kelas VIII A dan VIII C sebagai sampel penelitian. Dilakukan juga uji t dua arah pada data nilai ujian tengah smester kedua kelas sampel dan diperoleh $t$ hitung 0,50 dan $t$ tabel 2,00 yang artinya kemampuan awal kedua kelas sama.

Teknik pengumpulan data dalam penelitian ini adalaah lembar observasi dan tes soal matematika. lembar observasi terdiri dari lembar observasi siswa, guru dan keterlaksanaan pembelajaran. Tes soal matematika yang terdiri dari 5 soal berupa soal uraian. Validasi instrumen yang digunakan pada penelitian ini berupa validitas isi oleh ahliyaitu dosen pendidikan matematika FKIP Universitas Mataram. Teknik analisis data pada penelitian ini adalah analisis statistik deskriptif dan analisis statistik inferensial dengan uji t dua sampel independen. Sebelumnya dilakukan uji asumsi yaitu uji normalitas dan homogenitas setelahnya dilakukan uji t dua arah. Uji hipotesis dengan uji $t$ untuk mengetahui perbedaanhasil belajar matematika siswa pada materi pola dan barisan bilangan kelas VIII SMPN 1 Gunungsari menggunakan model pembelajaran kooperatif tipe two stay two stray dan jigsaw tahun pelajaran 2019/2020.

\section{HASIL DAN PEMBAHASAN}

Analisis statistik deskriptif untuk mendeskripsikanhasil belajar matematikasiswa kelas VIIISMPN 1 Gunungsari. Adapun perhitungan statistik deskriptif hasil belajar adalah sebagai berikut.

Tabel 3. Hasil Analisis Deskriptif Data Hasil Post Test

\begin{tabular}{cccc}
\hline & & \multicolumn{2}{c}{ Kelas } \\
\hline No & Ukuran & VIII A & VIII C \\
\hline 1 & Jumlah Siswa & 30 & 30 \\
2 & Rata-Rata & 63,67 & 65,33 \\
3 & Simpangan & 13,06 & 12,78 \\
& Baku & & \\
4 & Nilai & 44 & 44 \\
& Terrendah & & \\
5 & Nilai Tertinggi & 88 & 90 \\
6 & Ketuntasan & $26,66 \%$ & $30,00 \%$ \\
& Kelasikal & & \\
\hline
\end{tabular}

Berdasarkan hasil analisis deskriptif dapat dilihat bahwa hasil belajar kelas two stay two stray dan kelas jigsaw belum mencapai KKM. Setelahnya dilakukan pengelompokan hasil belajar siswa dengan hasil pengelompokan sebagai berikut:
Tabel 4. Data Pengelompokan Hasil Belajar Siswa

\begin{tabular}{cccc}
\hline Kelas & $\begin{array}{c}\text { Keriteria } \\
\text { Pengelompokan }\end{array}$ & Kategori & $\begin{array}{c}\text { Jumlah } \\
\text { Siswa }\end{array}$ \\
\hline VIII & $\mathrm{x} \geq 77,27$ & Tinggi & 6 \\
A & $50,61 \leq \mathrm{x}<$ & Sedang & 17 \\
& 77,27 & & \\
& $\mathrm{x}<50,61$ & Rendah & 7 \\
VIII & $52,55 \leq \mathrm{x}<$ & Sedang & 17 \\
C & 78,11 & & \\
& $\mathrm{x}<52,55$ & Rendah & 5 \\
\hline
\end{tabular}

Dari hasil pengelompokan hasil belajar siswa nampak bahwa hasil belajar untuk kelas two stay two stray dan jigsaw tidak terlalu berbeda. Namun untuk kelas jigsaw terlihat lebih unggul karena lebih banyak siswa yang memperoleh hasil belajar tinggi dibanding kelas two stay two stray.

Selanjutnya dilakukan uji statistik inferensial yang dimulai dengan uji prasyarat terlebih dahulu.

1) Uji Normalitas

Berdasarkan analisis uji normalitas data dengan uji lilieforsdiperoleh nilai $L_{\text {hitung }}$ untuk kelas two stay two stray dan kelas jigsaw adalah 0,12 dan $L_{\text {tabel }}$ adalah 0,16 . Dimananilai $L_{\text {hitung }}<L_{\text {tabel }}$ maka hasil uji normalitas hasil belajar kedua kelas berdistribusi normal.

2) Uji Homogenitas

Berdasarkan analisis uji homogenitas dengan uji F Diperoleh nilai $F_{\text {hitung }}$ adalah 1,04 dan $F_{\text {tabel }}$ adalah 1,86. karena $F_{\text {hitung }}<$ $F_{\text {tabel }}$ maka data dari nilai post test kelas VIII A dan kelas VIII C memiliki variansi yang homogen.

3) Uji $t$

Untuk melihat perbedaan signifikan hasil belajar matematika siswa kelas two stay two stray dan kelas jigsawmaka dilakukan uji t dengan uji t dua arah. Diperoleh harga $t_{\text {hitung }}$ sebesar 0,48 ,sedangkan $t_{\text {tabel }}$ pada taraf signifikansi $5 \%$ adalah sebesar 2,00. Karena $t_{\text {hitung }}<t_{\text {tabel }}$ maka $H_{0}$ diterima. Oleh karena itu, dapat disimpulkan tidak terdapat perbedaan yang signifikan antara hasil belajar siswa kelas two stay two stray dan kelas jigsaw pada siswa kelas VIII SMPN 1 Gunungsari tahun pelajaran 2019/2020.

Berdasarkan hasil penelitian pada analisis data deskriptif terlihat bahwa terdapat perbedaaan antara hasil belajar kelas two stay two stray dan kelasjigsaw. Kelas yang mendapat perlakuan 
penerapan model pembelajran kooperatif tipe jigsaw memperoleh rata-rata hasil belajar yang lebih tinggi dibandingkan dengan hasil belajar kelas yang mendapat perlakuan penerapan model pembelajaran kooperatif tipe two stay two stray. Secara deskriptif, perbedaan hasil belajar dikarenakan kontrol kelas yang lebih sulit pada kelas two stay two stray yang mengakibatkan kurang terarahnya pembelajaran untuk mencapai tujuan pembelajaran. Kontrol kelas yang lebih sulit pada kelas two stay two stray ini terjadi pada tahap diskusi antar kelompok. Ketika berlangsungnya diskusi, dua anggota kelompok pada kelas two stay two stray akan berkeliling ke kelompok lain untuk memperoleh informasi yang belum dimiliki. Kegiatan berkeliling inilah yang menjadi awal lepasnya kontrol kelas karena siswa sering mengabaikan arahan guru dan berkeliling tidak sesuai dengan skema yang telah disiapkan. Hal ini semakin dikuatkan lagi oleh [4] bahwa jika kondisi belajar tetap kondusif, maka tujuan pengajaran akan tercapai, sehingga hasil belajar siswa menjadi lebih baik. Sedangkan kontrol kelas pada kelas eksperimen 2 ketika diskusi berlangsung dapat lebih diarahkan karena proses diskusi berlangsung di meja kelompok tanpa ada perpindahan selama berlangsungnya diskusi.

Dari hasil analisis statistikinferensil dapat disimpulkan bahwa tidak terdapat perbedaan yanng signifikan antara hasil belajar siswa kelas yang meemperoleh model pembelajaran two stay two stray dan hasil belajar siswa kelas yang memperoleh model pembelajaran jigsaw. Hal utama yang menyebabkan tidak adanya perbedaan hasil belajar yang signifikan dari kedua model pembelajaran adalah Karena kedua model pembelajaran pada dasarnya merupakan model pembelajaran kooperatif. Model pembelajaran two stay two stray maupun jigsaw sama-sama menggutamakan kerjasama dalam kelompok sehingga tujuan pembelajaran dapat tercapai. Hal ini sesuai dengan yang dikemukakan oleh Lie (2008) [7] bahwa pembelajaran kooperatif merupakan pembelajaran yang mengutamakan kerjasama dalam kelompok hingga mencapai tujuan bersama. Secara umum langkah-langkah pembelajaran pada kelas two stay two stray maupun kelas jigsaw mengikuti sintak model pembelajaran kooperatif. Dari hasil observasi keterlaksanaan pembelajaran terlihat bahwa keterlaksanan model pembelajaran pada kedua kelas hanya berbeda pada bagian proses diskusi sedangkan untuk proses yang lain sama. Dari kesamaan-kesamaan ini menjadi penyebab tidak adanya perbdaan yang signifikan antara hasil belajar siswa yang memperoleh model pembelajaran kooperatif tipe two stay two stray dan yang menerapkan model pembelajaran kooperatif tipe jigsaw. Hasil penelitian ini sesuai dengan hasil penelitian [2] yang juga mengatakan bahwa tidak ada perbedaan yang signifikan hasil belajar siswa antara model pembelajaran kooperatif tipe jigsaw dan tipe two stay two stray. Selain membandingkan rata-rata hasil belajar siswa pada kelas two stay two stray dengan jigsaw dilihat juga hasil belajar siswa dari Kriteria Ketuntasan Minimum (KKM). Rata-rata hassil belajar kelas two stay two stray maupun kelas jigsaw belum meencapai KKM atau lebih rendah dari KKM. Namun pada kedua kelas ada beberapa siswa yang nilainya mencapai bahkan melebihi KKM. Pada kelas two stay two stray ada delapan siswa dan pada kelas jigsaw ada sembilan siswa yang nilainya mencapai KKM. Sedikitnya siswa yang dapat mencapai KKM disebabkan karena faktor-faktor dari guru, siswa itu sendiri dan faktor-faktor lainnya.

Dari segi guru karena belum terbiasanya guru dalam melaksanakan pembelajaran menggunakan model pembelajaran koopertif tipe two stay two stray maupun jigsaw. Selain dari segi penguasaan model pembelaajaran guru juga masih belum sepenuhnya dapat menjalankan model pembelajaran sehingga masih mengalaami kesulitan dalam pengelolaan kelas. Sedangkan dari segi siswa sendiri disebabkan karena siswa belum terbiasa melaksanakan pembelajaran dengan model berkelompok. Penerapana model pembelajaran dengan tahapan-tahapan yang masih asing bagi siswa mengakibatkan siswa menjadi kebingungan. Selain itu kemampuan komunikasi siswa dalam diskusi akan menentukan tersampaikan atau tidaknya informasi secara menyeluruh kepada setiap siswa. Hal ini sangat mempengaruhi hasil belajar siswa mengingat bahwa sumber informasi utama dari pembelajaran dengan kedua model ini adalah siswa itu sendiri. Keadaan ini sesuai dengan hasil penelitian [1] bahwa kemampuan komunikasi mempengaruhi pengaruh terhadap hasil belajar siswa sehingga hasil belajar siswa yang memiliki kemampuan komunikasi tinggi lebih tinggi dibandingkan siswa dengan kemampuan komunikasi rendah.

Selain dari segi guru dan siswa, faktorfaktor lain selama pelaksanaan pembelajaran juga sangat mempengaruhi hasil belajar siswa. Faktor lainnya yang sangat terlihat ialah waktu pelaksanaan pembelajaran. Waktu pelaksanaan pembelajaran yang dimulai pada siang hari menjadikan siswa kesulitan untuk berkonsentrasi selama proses pembelajaraan. Konsentrasi belajar siswa yang rendah mengakibatkan ketidakseriusan dalam belajar dan daya pemahaman terhadap materi menjadi berkurang sehingga hasil belajar siswa menjadi rendah [3]. Waktu pelaksanaan pembelajaran mempunyai kontribusinya sendiri dalam keberhasilan pembelajaran. Hal ini didukung [6] bahwa 
seorang siswa akan dapat mencapai keberhasilan dalam belajar, jika ia memiliki waktu yang tepat untuk belajar. Jadi secara umum hasil belajar matematika siswa setelah diterapakan model pembelajaran kooperatif tipetwo stay two stray maupun jigsaw belum dapat mencapai KKM yang telah ditentukan.

\section{KESIMPULAN}

Berdasarkan analisis data dan pembahasan maka dapat disimpulkan bahwa tidak terdapat perbedaan hasil belajar matematika siswa pada materi pola dan barisan bilangan setelah diterapkannya model pembelajaran kooperatif tipe two stay two stray dan jigsaw pada siswa kelas VIII SMPN 1 Gunungsari tahun pelajaran 2019/2020.

\section{DAFTAR PUSTAKA}

[1] Anggraeni, Viana Teti, dkk. 2014. Dampak Komunikasi Siswa Terhadap Hasil Belajar Matematika Sekolah Dasar.Varia Pendidikan 26(1):69-76.

[2] Anwar, Miftahul, dkk. 2018. Perbandingan Model Pembelajaran Kooperatif Tipe JigsawDan Tipe TwoStay Two Stray Terhadap Hasil Belajar Siswa Pada Materi Elastisitas. EduFisika 3(2): 13-21.

[3] Aviana, Ria dan Fitria Fatichatul Hidayah. 2015. Pengaruh Tingkat Konsentrasi Belajar Siswa terhadap DayaPemahaman Materi Pada Pembelajaran Kimiadi SMA Negeri 2 Batang. Jurnal Pendidikan Sains.Vol. 3(1):30-33.

[4] Chamidah, Nur. 2014. Pengaruh Pengelolaan Kelas Terhadap Prestasi Belajar IPS Siswa Kelas IV SD Negeri Margoyasan. Yogyakarta: UNY

[5] Hosnan. 2014. Pendekatan Saintifik dan Kontekstual Dalam Pembelajaran Abad 21. Bogor: Ghalia Indonesia.

[6] Lestari, Indah. 2017. Pengaruh Waktu belajar dan Minat Belajar terhadap Hasil
Belajar Matematika. Jurnal Formatif. Vol. 3(2): 115-125

[7] Nur, AmaliaRizki. 2018. Perbandingan Motivasi Dan Hasil Belajar Melalui Model Pembelajaran Kooperatif Tipe Two Stay Two Stray (TSTS) Dan Tipe Group Investigation (GI). 2010. Prosedur Penelitian Suatu Pendekatan Praktik.Vol. 6(1): 119-130.

[8] Rusman. 2017. Belajar \& Pembelajaran Berorientasi Standar Proses Pendidikan. Jakarta: Prenada Media.

[9] Wanna. Djair. 2016. Comparison Of The Effectivines Of Cooperative Learning Two Stay Two Stray And Jigsaw Type WithScientific Approach On Learning Mathematics LearningTo Grade XI MIA At Man Pangkep. Jurnal Daya Matematis 4 (3) : 280-305.

[10] Triowathi, N., \& Wijayanti, A. (2018). Implementasi team games tournament (tgt) dalam meningkatkan kerjasama dan hasil belajar IPA. Jurnal Pijar Mipa, 13(2), 110118.

[11] Gayatri, I. G. A. S., Jekti, D. S. D., \& Jufri, A. W. (2013). Efektifitas pembelajaran berbasis masalah (PBM) dan strategi kooperatif terhadap kemampuan menyelesaikan masalah dan hasil belajar kognitif biologi ditinjau dari kemampuan akademik awal siswa kelas X SMA Negeri 3 Mataram. Jurnal Pijar Mipa, 8(2).

[12] Susanti, A., \& Wijayanti, A. (2017). Think Pair Share: Hasil Belajar IPA dan Kerjasama Siswa. Jurnal Pijar Mipa, 12(2), 51-59.

[13] Ismah, Z., \& Ernawati, T. (2018). Pengaruh Model Pembelajaran Kooperatif Tipe Teams Games Tournament (TGT) Terhadap Hasil Belajar Ipa Siswa Kelas VIII SMP Ditinjau Dari Kerjasama Siswa. Jurnal Pijar Mipa, 13(1), 82-85. 